\title{
Evaluation of the distribution of nicotine intravenous injection: an adult autopsy case report with a review of literature
}

\author{
Yayoi Aoki ${ }^{1}$ (D) Tomoya Ikeda ${ }^{1,2} \cdot$ Naoto Tani ${ }^{1,2} \cdot$ Alissa Shida $^{1} \cdot$ Shigeki Oritani ${ }^{1} \cdot$ Takaki Ishikawa $^{1,2}$
}

Received: 5 February 2019 / Accepted: 27 February 2019 /Published online: 7 April 2019

(C) The Author(s) 2019

\begin{abstract}
We reported the first comprehensive autopsy case of death due to intravenous injection of nicotine. We examined the distribution of nicotine in the body tissues and fluid and exposed the pathophysiology of nicotine poisoning. A 19-year-old woman was rushed to the hospital in cardiorespiratory arrest and was confirmed dead upon arrival. Liquid nicotine, hydrogen peroxide water, and a syringe were found in the hotel room where she stayed. On autopsy, nicotine concentration was the highest $(15,023 \mu \mathrm{g} / \mathrm{mg})$ in the tissue around the injection mark on the right upper arm. Among the body fluids, the intraperitoneal fluid had the highest, whereas the pericardial fluid had the lowest $(0.736 \mu \mathrm{g} / \mathrm{mL})$ nicotine concentration. Among the organs, the brain had the highest $(11.637 \mu \mathrm{g} / \mathrm{mg})$, whereas the fat tissue had the lowest $(1.307 \mu \mathrm{g} / \mathrm{mg})$ nicotine concentration. The concentration of cotinine, which is the metabolite of nicotine, was the highest in the tissue around the injection mark on the right arm $(5.495 \mu \mathrm{g} / \mathrm{mg})$ and was almost the same among the other body fluids and organs. The respective concentrations of nicotine and cotinine were $1.529 \mu \mathrm{g} /$ $\mathrm{mL}$ and $0.019 \mu \mathrm{g} / \mathrm{mL}$ in the left heart blood and $3.157 \mu \mathrm{g} / \mathrm{mL}$ and $0.002 \mu \mathrm{g} / \mathrm{mL}$ in right heart blood. In this case, the nicotine concentrations in blood reached the lethal level. The distributions of nicotine and cotinine, as indicated by the intravenous injection, were related to the distribution of organs that metabolize nicotine and the distribution of nicotinic acetylcholine receptors.
\end{abstract}

Keywords Nicotine $\cdot$ Cotinine $\cdot$ Intravenous injection $\cdot$ Acetylcholine receptors $\cdot$ Forensic autopsy

\section{Introduction}

Nicotine is an amphipathic alkaloid that is contained in familiar products, such as tobacco, nicotine gums, and nicotine patches. It can be highly addictive and is highly toxic [1-5]. Nicotine absorbed into the body or blood vessels migrate to the brain first [6], and this migration is heavily influenced by the distribution of nicotinic acetylcholine receptors [7]. After this migration, nicotine flows via the bloodstream to the other organs, especially the muscles, spleen, liver, and kidneys [8]. Nicotine is metabolized in the liver, and $70 \%$ is metabolized to

Yayoi Aoki

aoki.yayoi@med.osaka-cu.ac.jp

1 Department of Legal Medicine, Osaka City University Medical School, 1-4-3 Asahi-machi, Abeno, Osaka 545-8585, Japan

2 Forensic Autopsy Section, Medico-legal Consultation and Postmortem Investigation Support Center, c/o Department of Legal Medicine, Osaka City University Medical School, 1-4-3 Asahi-machi, Abeno, Osaka 545-8585, Japan cotinine by enzymes [9]. The half-life of nicotine is approximately $20 \mathrm{~min}$ to $2 \mathrm{~h}$, but the half-life of cotinine is $20 \mathrm{~h}$. Moreover, cotinine lodges in the body longer than nicotine [10] before being excreted through the kidneys; notably, $10 \%$ of nicotine is excreted in urea without being metabolized [11].

Until now, there had been several reports on cases of poisoning from intraperitoneal nicotine and nicotinecontaining products, mainly in infants [12-17]. However, few have reported about poisoning from intravenous nicotine in adults $[18,19]$; in fact, there was only one international literature about fatal intravenous nicotine poisoning [20]. In that study, however, a forensic pathologic autopsy was not performed, and there was no information aside from blood concentration (Table 1).

We experienced a rare case of death resulting from intravenous injection of undiluted nicotine. In this case, several body fluids, including blood, and organs were collected. To our best knowledge, this was the first case that reported the distribution of nicotine and cotinine in the body after intravenous nicotine injection. 
Table 1 Review of international literature on cases of nicotine injection, including the present case

\begin{tabular}{|c|c|c|c|c|c|c|c|c|}
\hline Case & $\begin{array}{l}\text { Age/ } \\
\text { Sex }\end{array}$ & Suicide/murder & Nicotine type & $\begin{array}{l}\text { Survival } \\
\text { period } \\
\text { (h) }\end{array}$ & $\begin{array}{l}\text { Nicotine } \\
\text { concentration } \\
\text { (blood) }\end{array}$ & Prognosis & $\begin{array}{l}\text { Cause of death/ } \\
\text { diagnosis }\end{array}$ & Publication \\
\hline 1 & $29 / \mathrm{M}$ & Suicide & e-Liquid & 120 & $2.1 \mu \mathrm{g} / \mathrm{mL}$ & Death & Nicotine poisoning & $\begin{array}{l}\text { Thornton et al. } 2014 \\
\text { [20] }\end{array}$ \\
\hline 2 & $27 / \mathrm{F}$ & $\begin{array}{l}\text { Attempted } \\
\text { suicide }\end{array}$ & Cigarette soakage & 36 & $<0.005 \mu \mathrm{g} / \mathrm{mL}$ & Recovery & Nicotine poisoning & Hagiya et al. 2010 [18] \\
\hline 3 & $32 / \mathrm{M}$ & $\begin{array}{l}\text { Attempted } \\
\text { suicide }\end{array}$ & e-Liquid & 24 & $1.3 \mu \mathrm{g} / \mathrm{mL}$ & Recovery & Nicotine poisoning & $\begin{array}{l}\text { Sommerfeld et al. } \\
2016 \text { [19] }\end{array}$ \\
\hline 4 & $19 / \mathrm{F}$ & Unknown & $\begin{array}{l}\text { Undiluted } \\
\text { nicotine }\end{array}$ & 2 & $0.002 \mu \mathrm{g} / \mathrm{mL}$ & Death & Nicotine poisoning & Present case \\
\hline
\end{tabular}

\section{Case history}

A 19-year-old woman was brought to the hospital in cardiorespiratory arrest. Four and $1 / 2 \mathrm{~h}$ prior, she was noted to be well and about to recuperate in a hotel room where she stayed as a tourist. Two hours and 20 min later, she was found by her husband lying unconscious on the bathroom floor and unresponsive. About an hour after, the emergency response team assessed her to be in cardiorespiratory arrest. She was brought to the hospital but was subsequently declared dead despite appropriate management. At $3 \mathrm{~h}$ and 20 min after being proclaimed dead, her rectal temperature was $34{ }^{\circ} \mathrm{C}$ at a room temperature of $21^{\circ} \mathrm{C}$.

According to her husband, she did not frequently go to the hospital, although she had symptoms of depression and had experiences of slashing her wrists. She was not a smoker, but she was said to drink alcohol and habitually used to take unknown medicines. A syringe was found on the toilet paper holder in the bathroom. Initially, her husband explained that it was used for mixing some e-Liquid for electronic cigarette. Subsequent police investigation found a green bottle and a green paper case that contained hydrogen peroxide in the room. About $36 \mathrm{~h}$ after, a forensic autopsy was performed to investigate the cause of her death.

\section{Results}

\section{Postmortem imaging}

Postmortem computed tomography (CT) showed the presence of moderate to severe pulmonary edema and minimal emphysematous changes in the periphery.

\section{Autopsy findings}

The subject was $159 \mathrm{~cm}$ tall and weighed $45.3 \mathrm{~kg}$, with a body mass index of 17.9. She had dark reddish-purple hypostasis with petechiae on her back. Her face was moderately congested. The palpebral conjunctivae were congested, with few petechiae. Injection marks with subcutaneous hemorrhage were seen on the right upper arm (Fig. 1a) and left elbow fossa and ran along the course of the blood vessel (Fig. 1b). Both left and right heart blood contained thin dark red blood without clots. The brain weighed $1285 \mathrm{~g}$ and was edematous and swollen. The left lung weighed $380 \mathrm{~g}$ and the right lung weighed $385 \mathrm{~g}$; both lungs were moderately congested and had parenchymal hemorrhage. The other organs were congested. There was no special structural finding.
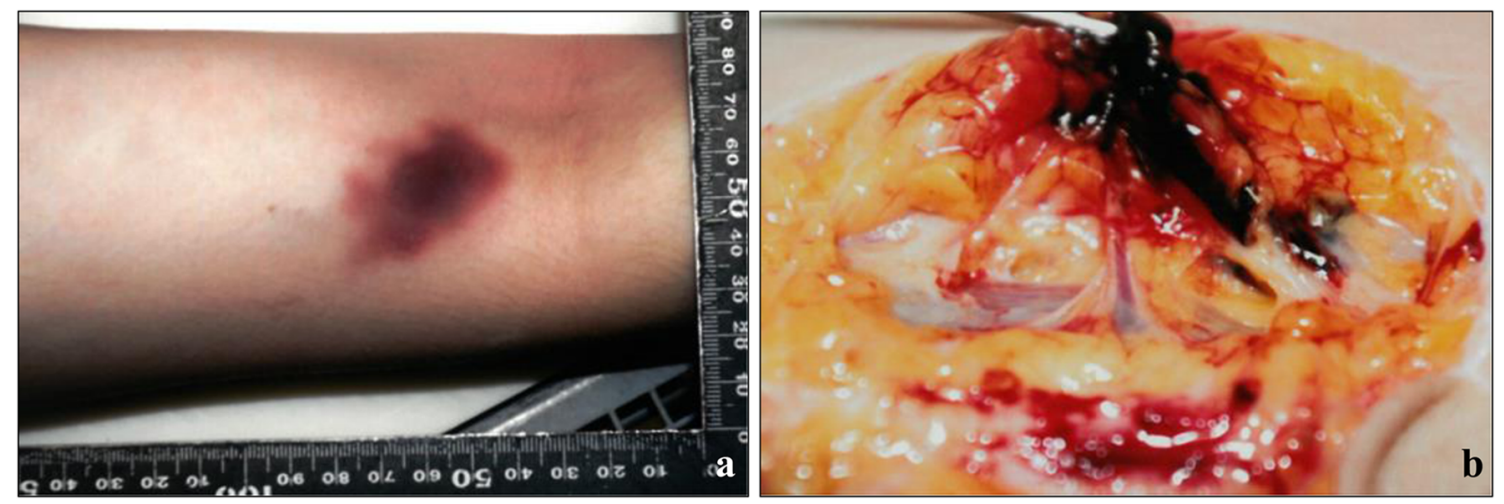

Fig. 1 Macropathologic findings in the injection mark on the right upper arm. a There is subcutaneous hemorrhage on the right upper arm. $\mathbf{b}$ The injection marks are along the blood vessel 


\section{Histologic examination}

Examination of the lungs showed diffusely edematous and congested intraalveolar spaces and interstitial tissues, some hemorrhages with alveolar injury, and emphysematous changes in the periphery. There were some food debris and bacterial conglomeration from the gastric contents in the bronchioles.

There were hemorrhages in the subcutaneous tissues around the injection marks. The mucosal membrane and microvessels in the subcutaneous tissues were damaged and showed hemorrhage from the injection (Fig. 2a, b).

\section{Postmortem biochemistry}

The levels of C-reactive protein $(0.04 \mathrm{mg} / \mathrm{dL})$ and neopterin $(112 \mathrm{pmol} / \mathrm{mL})$, which are both markers of systemic inflammation, were not elevated in the right heart blood [21, 22]. However, the interleukin-6 (IL-6) levels were elevated in the right heart blood $(338 \mathrm{pg} / \mathrm{mL})$ and left heart blood $(5870 \mathrm{pg} /$ $\mathrm{mL}$ ). In adult cases, serum IL-6 levels above $1000 \mathrm{pg} / \mathrm{mL}$ indicate early-stage systemic inflammation [23, 24]. The concentrations of several serum markers, including creatinine $(1.48 \mathrm{mg} / \mathrm{dL})$, blood urea nitrogen $(11.6 \mathrm{mg} / \mathrm{mL})$, and uric acid $(9.7 \mathrm{mg} / \mathrm{mL})$, were in the forensic pathology normal range. In this case, there was no forensic biochemical evidence of abnormal renal function and skeletal muscle injury, such as rhabdomyolysis $[25,26]$. Although the myoglobin concentrations in the cerebrospinal fluid $(26,700 \mathrm{ng} / \mathrm{mL})$ and pericardial fluid $(662,000 \mathrm{ng} / \mathrm{mL})$ were markedly high, these did not indicate the typical rhabdomyolysis level $[27,28]$. The respective pericardial and cerebrospinal fluid catecholamine levels exceeded the pathological cutoff levels (adrenaline, $184,000 \mathrm{pg} / \mathrm{mL}$ and $2341 \mathrm{pg} / \mathrm{mL}$; noradrenaline, 205,260 pg/mL and $2741 \mathrm{pg} / \mathrm{mL}$; and dopamine, $8801 \mathrm{pg} /$ $\mathrm{mL}$ and $436 \mathrm{pg} / \mathrm{mL}$ ). The catecholamine levels in the pericardial and cerebrospinal fluids were indicative of drug

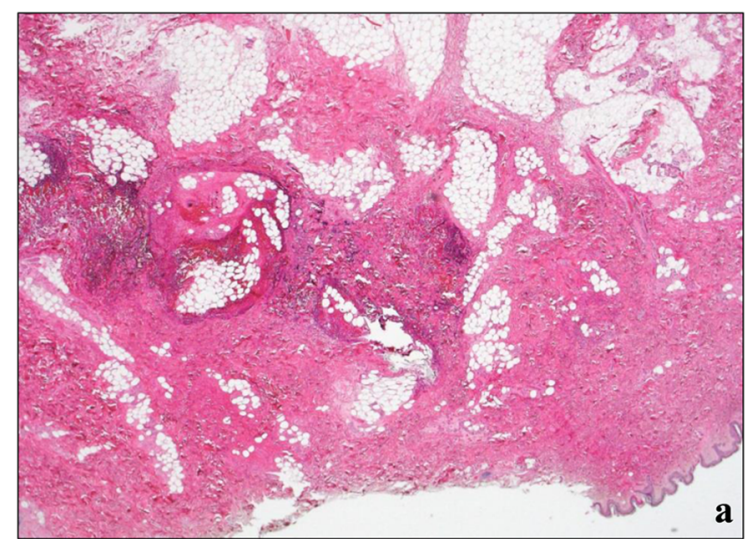

Fig. 2 Histopathologic findings of the injection marks on the right upper arm. a The mucosal membrane and microvessels in the subcutaneous tissues are damaged and show hemorrhage from the injection intoxication [29]. Serum tryptase, which is a marker of anaphylactic shock, was not elevated. The increased levels of immunoglobulin E $(95.5 \mathrm{IU} / \mathrm{mL})$, histamine $(14.7 \mathrm{ng} / \mathrm{mL})$, and tryptase $(1.8 \mu \mathrm{g} / \mathrm{L})$ were unremarkable [30]. Postmortem biochemical analysis showed no findings indicative of hepatic dysfunction (direct bilirubin, $0.3 \mathrm{mg} / \mathrm{dL}$ ) and chronic heart failure (human atrial natriuretic polypeptide, $64.4 \mathrm{pg} / \mathrm{mL}$; brain natriuretic peptide, $74.4 \mathrm{pg} / \mathrm{mL}$ ) [31].

\section{Toxicologic examination}

\section{Toxicologic screening}

Toxicologic examinations of pericardial fluid samples for drug screening using Triage ${ }^{(}$(Biosite Diagnostic Inc., San Diego, CA, USA) and gas chromatography-mass spectrometry (GCMS) were negative.

\section{Sample preparation}

Samples were extracted using supported liquid extraction (SLE) solid/ liquid phase extraction columns. Standard calibration curves were constructed using blank human serum and $0.1,0.5$, and $1 \mu \mathrm{g}$ of nicotine and cotinine. Diazepam-D5 $(50 \mu \mathrm{g})$, which was used as an internal standard, was added to each $0.5 \mathrm{~mL}$ sample. Acetonitrile was added in ratios of $0.5 \mathrm{~mL}$ to $0.5 \mathrm{~mL}$ to blood, $0.3 \mathrm{~mL}$ to $0.2 \mathrm{~mL}$ to gastric contents, and $0.4 \mathrm{~mL}$ to $0.1 \mathrm{~mL}$ to bile. Next, the samples were vortexed and centrifuged at 10,000 rpm for $30 \mathrm{~s}$, and the supernatants $(250 \mu \mathrm{L})$ and aqueous samples $(250 \mu \mathrm{L})$ were loaded onto the SLE columns. Organs were prepared by tissue homogenization and were centrifuged at $10,000 \mathrm{rpm}$ for $30 \mathrm{~s}$; the supernatants $(250 \mu \mathrm{L})$ were again loaded onto the SLE columns. After sample loading, the columns were successively washed with $1.3 \mathrm{~mL}$ of a mixture of isopropanol and dichloromethane (20:80), followed by

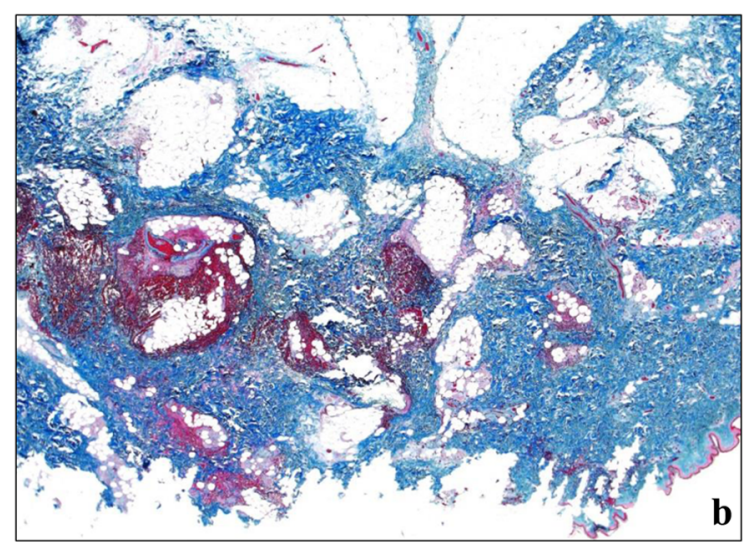

(hematoxylin-eosin stain, original magnification $\times 20$ ). $\mathbf{b}$ There are no findings of fibrosis and fibroblasts from the old injection marks (azan stain, original magnification $\times 20$ ) 
$1.3 \mathrm{~mL}$ of dichloromethane. The eluates were collected and evaporated to dryness under a gentle stream of nitrogen. The residues were reconstituted in $50 \mu \mathrm{L}$ of ethyl acetate, and aliquots of the extracts were analyzed by GC-MS using an Agilent model 5975c MSD system equipped with a DB$5 \mathrm{MS}$ column (length $30 \mathrm{~m}$; id $0.25 \mathrm{~mm}$; film thickness $0.25 \mu \mathrm{m}$; Agilent Technologies, Palo Alto, CA, USA). The analysis conditions were as follows: column temperature, $100{ }^{\circ} \mathrm{C}$ to $325{ }^{\circ} \mathrm{C}$; injector temperature, $280{ }^{\circ} \mathrm{C}$; turbocharged carrier gas, helium at a flow rate of $48 \mathrm{~cm} / \mathrm{s}$; and interface temperature, $300{ }^{\circ} \mathrm{C}$. At our facility, the recovery of standards ranged from $60-70 \%$ to $>95 \%$. The limit of quantification was defined as the lowest analyte concentration that could be specifically measured and corresponded in the presence of three transitions. Our analyses were based on our previously reported methods $[32,33]$.

\section{Results of toxicologic examination}

The sample concentrations of nicotine and cotinine quantified by the GC-MS are shown in Tables 2 and 3.

\section{Body fluids}

Nicotine: The concentration was the highest in the intraperitoneal fluid $(7.65 \mu \mathrm{g} / \mathrm{mL})$ and the lowest in the pericardial fluid $(0.73 \mu \mathrm{g} / \mathrm{mL})$. The concentration in the left heart blood $(1.52 \mu \mathrm{g} / \mathrm{mL})$ was lower than those in the right heart blood $(3.15 \mu \mathrm{g} / \mathrm{mL})$ and the iliac vein blood $(3.10 \mu \mathrm{g} / \mathrm{mL})$ (Table 2; sample group I).
Cotinine: All samples showed low concentrations of less than $0.1 \mu \mathrm{g} / \mathrm{mL}$. There was no significant difference among the samples (Table 3; sample group I).

Ethanol: No significant concentrations of ethanol and other drugs were detected in both the left heart and right heart blood, as well as in the gastric contents.

\section{Organs}

Nicotine: The highest concentration was in the temporal lobe of the cerebrum $(11.63 \mu \mathrm{g} / \mathrm{mg})$, followed by the right kidney $(5.24 \mu \mathrm{g} / \mathrm{mg})$ and the lung $(4.80 \mu \mathrm{g} / \mathrm{mg})$. There was no significant difference in the nicotine concentrations among the other organs $(2.89-5.24 \mu \mathrm{g} / \mathrm{mg})$. The least concentration was in the fat tissues $(1.30 \mu \mathrm{g} / \mathrm{mg})$ (Table 2; sample group II).

Cotinine: The concentration was the highest in the greater pectoral muscle $(0.85 \mu \mathrm{g} / \mathrm{mg})$ and the lowest in the right kidney $(0.028 \mu \mathrm{g} / \mathrm{mg})$. There was no significant difference in the nicotine concentrations among the other samples $(0.05-$ $0.35 \mu \mathrm{g} / \mathrm{mg}$ ) (Table 3; sample group II).

\section{Tissues around the injection marks}

Nicotine: The concentration in the tissue around the injection site on the right upper arm $(15,023 \mu \mathrm{g} / \mathrm{mg})$ was the highest. The concentrations in the other injection sites were $1.66 \mu \mathrm{g} /$ $\mathrm{mg}$ in the left cubital fossa and $1.04 \mu \mathrm{g} / \mathrm{mg}$ in the left forearm (Table 2; sample group III).

Cotinine: The concentration was the highest in the tissue around the injection site of nicotine on the right upper arm $(5.49 \mu \mathrm{g} / \mathrm{mg})$. However, the concentrations in the other tissues

Table 2 Distribution of nicotine concentrations in this case

\begin{tabular}{|c|c|c|c|c|c|}
\hline \multicolumn{2}{|l|}{ Sample group I (body fluids) } & \multicolumn{2}{|l|}{ Sample group II (organs) } & \multicolumn{2}{|c|}{$\begin{array}{l}\text { Sample group III (around the tissue } \\
\text { injection mark) }\end{array}$} \\
\hline Sample & Nicotine $(\mu \mathrm{g} / \mathrm{mL})$ & Sample & Nicotine $(\mu \mathrm{g} / \mathrm{mg})$ & Sample & Nicotine $(\mu \mathrm{g} / \mathrm{mg})$ \\
\hline Intraperitoneal fluid & 7.654 & Brain (temporal lobe) & 11.637 & Upper arm (right) & $15,023.493$ \\
\hline Aqueous humor (left) & 6.226 & Kidney (right) & 5.242 & Cubital fossa (left) & 1.669 \\
\hline Aqueous humor (right) & 5.850 & Lung (right lower lobe) & 4.808 & Forearm (left) & 1.040 \\
\hline Pleural effusion (left) & 5.654 & Ovary (left) & 3.984 & & \\
\hline Pleural effusion (right) & 4.625 & Liver & 3.704 & & \\
\hline Bile & 4.446 & Spleen & 3.615 & & \\
\hline Stomach contents & 4.269 & Heart & 3.480 & & \\
\hline Heart blood (right) & 3.157 & Skin (chest) & 3.344 & & \\
\hline Peripheral blood (iliac vein) & 3.109 & Uterus & 3.229 & & \\
\hline Bone marrow & 2.701 & Pancreas & 3.215 & & \\
\hline Heart blood (left) & 1.529 & Ovary (right) & 3.130 & & \\
\hline \multirow[t]{2}{*}{ Pericardial fluid } & 0.736 & Muscle (pectoral muscle) & 2.897 & & \\
\hline & & Fat tissue (abdominal subcutaneous & 1.307 & & \\
\hline
\end{tabular}


Table 3 Distribution of cotinine concentrations in this case

\begin{tabular}{|c|c|c|c|c|c|}
\hline \multicolumn{2}{|l|}{ Sample group I (body fluids) } & \multicolumn{2}{|l|}{ Sample group II (organs) } & \multicolumn{2}{|c|}{$\begin{array}{l}\text { Sample group III (around the tissue } \\
\text { injection mark) }\end{array}$} \\
\hline Sample & Nicotine $(\mu \mathrm{g} / \mathrm{mL})$ & Sample & Nicotine $(\mu \mathrm{g} / \mathrm{mg})$ & Sample & Nicotine $(\mu \mathrm{g} / \mathrm{mg})$ \\
\hline Stomach contents & 0.096 & Muscle (pectoral muscle) & 0.853 & Upper arm (right) & 5.495 \\
\hline Aqueous humor (right) & 0.096 & Lung (right lower lobe) & 0.353 & Forearm (left) & 0.133 \\
\hline Pleural effusion (left) & 0.048 & Liver & 0.280 & Cubital fossa (left) & 0.114 \\
\hline Pleural effusion (right) & 0.043 & Uterus & 0.200 & & \\
\hline Pericardial fluid & 0.035 & Ovary (right) & 0.181 & & \\
\hline Bile & 0.034 & Pancreas & 0.178 & & \\
\hline Aqueous humor (left) & 0.026 & Spleen & 0.138 & & \\
\hline Heart blood (left) & 0.019 & Ovary (left) & 0.135 & & \\
\hline Peripheral blood (iliac vein) & 0.015 & Heart & 0.132 & & \\
\hline Bone marrow & 0.014 & Brain (temporal lobe) & 0.125 & & \\
\hline Intraperitoneal fluid & 0.003 & Skin (chest) & 0.104 & & \\
\hline Heart blood (right) & 0.002 & Fat tissue (abdominal subcutaneous fat) & 0.054 & & \\
\hline & & Kidney (right) & 0.028 & & \\
\hline
\end{tabular}

around the injection site were not significant (left cubital fossa, $0.11 \mu \mathrm{g} / \mathrm{mg}$; left forearm, $0.13 \mu \mathrm{g} / \mathrm{mg}$ ) (Table 3; sample group III).

\section{Hydrogen peroxide solution}

The left and right heart blood and aqueous humor concentrations of the hydrogen peroxide solution found in the room were quantified using hydrogen peroxide colorimetric detection kit (Cosmo Bio Co., Ltd., Tokyo, Japan) and Multiskan FC (Thermo Fisher Scientific, MA, USA) [34, 35]. The concentrations in the left $(31.43 \mu \mathrm{M})$ and right $(46.82 \mu \mathrm{M})$ heart blood and iliac vein $(27.78 \mu \mathrm{M})$ were within the normal range of a healthy person. Furthermore, the concentrations of hydrogen peroxide were $10.27 \mu \mathrm{M}$ in the pericardial fluid; $10.04 \mu \mathrm{M}$ in the left and $10.29 \mu \mathrm{M}$ in the right pleural fluid; and $5.39 \mu \mathrm{M}$ in the left and $5.53 \mu \mathrm{M}$ in the right vitreous humor.

\section{Discussion}

In the present case, there were injection marks on the bilateral upper limbs. Notably, the nicotine concentration was extremely high at $15,023 \mu \mathrm{g} / \mathrm{mg}$ in the tissues around the injection mark on the right upper arm and reached a lethal level of 1.52 to $3.15 \mu \mathrm{g} / \mathrm{mL}$ in the blood (lethal cutoff $>1.4 \mu \mathrm{g} / \mathrm{mL}$ ) [36-38]. The lungs were edematous and congested, with alveolar parenchyma hemorrhage, and the brain was swollen. Therefore, we concluded that the cause of death was intravenous nicotine poisoning. The body fluid drug screening test by GC-MS revealed the presence of nicotine and its metabolite cotinine, but no other drugs were detected. However, we could not show scientific evidence of suicide.

The green bottle found in the room was confirmed to be hydrogen peroxide, although its level $(5.39-46.82 \mu \mathrm{M})$ was within the normal range $(13-57 \mu \mathrm{M})[39,40]$. Therefore, the hydrogen peroxide probably did not contribute to her death. Moreover, the markers of anaphylactic shock were not increased and there was no scientific evidence of rhabdomyolysis, based on the myoglobin biochemical examination and immunohistochemistry of the skeletal muscle [41, 42].

Several case reports were on oral ingestion of nicotine [43, 44]. However, in the present case the gastric concentration of nicotine was low. Moreover, the levels of nicotine and cotinine were higher in the left than in the right heart blood. The levels of cotinine, which has a long half-life, were low in almost all the samples, but the nicotine level in the injection mark on the right upper arm was extremely high. These findings implied that the nicotine was taken intravenously in the present case.

In general, the blood concentration of nicotine reaches approximately $10 \mathrm{ng} / \mathrm{mL}$ within a few minutes of smoking one cigarette; in the present case, the nicotine concentration in the blood samples was above that level. Intravenous injection of nicotine likely caused the death in the present case. The moment nicotine enters the body, it is metabolized into cotinine, which reaches a concentration that is $2-4$ times higher than that of nicotine within an hour. In the present case, the higher levels of nicotine than cotinine in all samples suggested an acute death due to the high concentration injected nicotine.

In the present case, the nicotine concentrations varied among the samples. Nicotine that enters the body through the bloodstream is immediately distributed to the brain and is metabolized for excretion in the kidney. The resulting 
distribution of nicotine is affected by the acetylcholine receptors in the body. The nicotinic acetylcholine receptor, which is an ionotropic receptor, is widely distributed in the brain; through its ligand, nicotine binds to the receptors to make changes in the body $[24,45]$. These receptors are also distributed in the nerves. Nicotine is also distributed in other sites, such as fat tissue [46], where it controls the production of adiponectin. In the present case, the lower nicotine level in the fat tissue than in the brain suggested that nicotine migrated to the brain within a few minutes after injection. The affinity of nicotine is higher to acetylcholine receptors in the brain than to fat tissue. However, nicotine is mainly metabolized in the liver not in the brain; therefore, the level of cotinine is expected to be low in the brain. In this case, there was no significant difference in the nicotine concentrations among the organs related to metabolism. This can probably be explained by the fact that the time it takes to metabolize nicotine depends on the injection speed and amount [29].

Recently, the methods of nicotine intake had been changing with the increasing use of electronic cigarettes. This means that some products that contain high concentrations of nicotine can be easily acquired, and nicotinerelated fatality rates can increase. A large database on the body distribution of nicotine and cotinine, based on quantification from as many samples as possible, will help estimate the route of nicotine intake in the field of forensic medicine and can be clinically useful for the medical treatment of acute nicotine poisoning cases.

Acknowledgments We are grateful to Ms. M. Ono for her collaboration and advice on the early stages of this work, as well as for her research in the previous years.

Data availability All data used to support the findings of this study are included within the article.

\section{Compliance with ethical standards}

Conflict of interest The authors declare that they have no conflict of interest.

Open Access This article is distributed under the terms of the Creative Commons Attribution 4.0 International License (http:// creativecommons.org/licenses/by/4.0/), which permits unrestricted use, distribution, and reproduction in any medium, provided you give appropriate credit to the original author(s) and the source, provide a link to the Creative Commons license, and indicate if changes were made.

\section{References}

1. Cashman JR, Park SB, Yang ZC, Wrighton SA, Jacob P 3rd, Benowitz NL (1992) Metabolism of nicotine by human liver microsomes: stereoselective formation of trans-nicotine N'-oxide. Chem Res Toxicol 5(5):639-346
2. Hosseinzadeh A, Thompson PR, Segal BH, Urban CF (2016) Nicotine induces neutrophil extracellular traps. J Leukoc Biol 100(5):1105-1112

3. O'Brien EK, Nguyen AB, Persoskie A, Hoffman AC (2017) U.S. adults' addiction and harm beliefs about nicotine and low nicotine cigarettes. Prev Med 96:94-100

4. Benowitz NL (1996) Pharmacology of nicotine: addiction and therapeutics. Annu Rev Pharmacol Toxicol 36:597-613

5. Oropesa AL, Floro AM, Palma P (2017) Toxic potential of the emerging contaminant nicotine to the aquatic ecosystem. Environ Sci Pollut Res Int 24(20):16605-16616

6. Benowitz NL (1990) Clinical pharmacology of inhaled drugs of abuse: implications in understanding nicotine dependence. NIDA Res Monogr 99:12-29

7. Hukkanen J, Jacob P 3rd, Benowitz NL (2005) Metabolism and disposition kinetics of nicotine. Pharmacol Rev 57(1):79-115

8. Benowitz NL, Hukkanen J, Jacob P 3rd (2009) Nicotine chemistry, metabolism, kinetics and biomarkers. Handb Exp Pharmacol 192: 29-60

9. Rubinstein ML, Shiffman S, Rait MA, Benowitz NL (2013) Race, gender, and nicotine metabolism in adolescent smokers. Nicotine Tob Res 15(7):1311-1315

10. Benowitz NL, Kuyt F, Jacob P 3rd (1982) Circadian blood nicotine concentrations during cigarette smoking. Clin Pharmacol Ther 32(6):758-764

11. Picciotto MR, Caldarone BJ, King SL, Zachariou V (2000) Nicotinic receptors in the brain: links between molecular biology and behavior. Neropsychopharmacology 22(5):451-465

12. Seo AD, Kim DC, Yu HJ, Kang MJ (2016) Accidental ingestion of e-cigarette liquid nicotine in a 15-month-old child: an infant mortality case of nicotine intoxication. Korean J Pediatr 59(12):490 493

13. Gill N, Sangha G, Poonai N, Lim R (2015) E-cigarette liquid nicotine ingestion in a child: case report and discussion. CJEM 17(6): 699-703

14. Solarino B, Rosenbaum F, Risselmann B, Buschmann CT, Tsokos M (2010) Death due to ingestion of nicotine-containing solution: case report and review of the literature. Forensic Sci Int 195(1-3): e19-e22

15. Bartschat S, Bender KMC, Beike J, Rothschild MA, Jübner M (2015) Not only smoking is deadly: fatal ingestion of e-juice a case report. Int J Legal Med 129(3):481-486

16. Chen BC, Bright SB, Trivedi AR, Valento M (2015) Death following intentional ingestion of e-liquid. Clin Toxicol 53(9):914-916

17. Corkery JM, Button J, Vento AE, Schifano F (2010) Two UK suicides using nicotine extracted from tobacco employing instructions available on the internet. Forensic Sci Int 199(1-3):e9-e13

18. Hagiya K, Mizutani T, Yasuda S, Kawano S (2010) Nicotine poisoning due to intravenous injection of cigarette soakage. Hum Exp Toxicol 29(5):427-429

19. Sommerfeld K, Łukasik-Glebocka M, Kulza M, Drużdż A, Panieński P, Florek E, Psuja BZ (2016) Intravenous and oral suicidal e-liquid poisonings with confirmed nicotine and cotinine concentrations. Forensic Sci Int 262:e15-e20

20. Thornton SL, Oller L, Sawyer T (2014) Fatal intravenous injection of electronic nicotine delivery system refilling solution. J Med Toxicol 10(2):202-204

21. Fujita MQ, Zhu BL, Ishida K, Quan L, Oritani S, Maeda H (2002) Serum C-reactive protein levels in postmortem blood-an analysis with special reference to the cause of death and survival time. Forensic Sci Int 130(2-3):160-166

22. Ishikawa T, Hamel M, Zhu BL, Li DR, Zhao D, Michiue T, Maeda $\mathrm{H}$ (2008) Comparative evaluation of postmortem serum concentrations of neopterin and C-reactive protein. Forensic Sci Int 179(2-3): $135-143$ 
23. Samraj RS, Zingarelli B, Wong HR (2013) Role of biomarkers in sepsis care. Shock 40(5):358-365

24. Palmiere C, Augsburger M (2014) Markers for sepsis diagnosis in the forensic setting: state of the art. Croat Med J 55(2):103-114

25. Zhu BL, Ishida K, Quan L, Taniguchi M, Oritani S, Li DR, Fujita MQ, Maeda H (2002) Postmortem serum uric acid and creatinine levels in relation to the cause of death. Forensic Sci Int 125(1):59 66

26. Zhu BL, Ishikawa T, Michiue T, Tanaka S, Zhao D, Li DR, Quan L, Oritani S, Maeda H (2007) Differences in postmortem urea nitrogen, creatinine and uric acid levels between blood and pericardial fluid in acute death. Legal Med 9(3):115-122

27. Zhu BL, Ishida K, Quan L, Taniguchi M, Oritani S, Kamikodai Y, Fujita MQ, Maeda H (2001) Post-mortem urinary myoglobin levels with reference to the causes of death. Forensic Sci Int 115(3):183188

28. Wang Q, Michiue T, Ishikawa T, Zhu BL, Maeda H (2011) Combined analysis of creatine kinase $\mathrm{MB}$, cardiac troponin I and myoglobin in pericardial and cerebrospinal fluids to investigate myocardial and skeletal muscle injury in medicolegal autopsy cases. Legal Med 13(5):226-232

29. Ishikawa T, Quan L, Michiue T, Kawamoto O, Wang Q, Chen JH, Zhu BL, Maeda H (2013) Postmortem catecholamine levels in pericardial and cerebrospinal fluids with regard to the cause of death in medicolegal autopsy. Forensic Sci Int 228(1-3):52-60

30. Mayer DE, Krauskopf A, Hemmer W, Moritz K, Jarisch R, Reiter C (2011) Usefulness of post mortem determination of serum tryptase, histamine oxidase in the diagnosis of fatal anaphylaxis. Forensic Sci Int 212(1-3):96-101

31. Zhu BL, Ishikawa T, Michiue T, Li DR, Zhao D, Tanaka S, Kamikodai Y, Tsuda K, Okazaki S, Maeda H (2007) Postmortem pericardial natriuretic peptides as markers of cardiac function in medico-legal autopsies. Int J Legal Med 121(1):28-35

32. Oritani S, Michiue T, Chen JH, Tani N, Ishikawa T (2017) Biodistribution of diphenhydramine in reproductive organs in an overdose case. Hum Cell 30:106-116

33. Ishikawa T, Yuasa I, Endoh M (2015) Non-specific drug distribution in an autopsy case report of fatal caffeine intoxication. Legal Med 17(6):535-538

34. Wojewodzka-Zelezniakowicz M, Kisiel W, Kramkowski K, Gromotowicz-Poplawska A, Zakrzeska A, Stankiewicz A,
Kolodziejczyk P, Szemraj J, Ladny JR, Chabielska E (2016) Quinapril decreases antifibrinolytic and prooxidative potential of propofol in arterial thrombosis in hypertensive rats. J ReninAngiotensin-Aldosterone Syst 17(2):1-12

35. Kim JS, Kwon WY, Suh GJ, Kim KS, Jung YS, Kim SH, Lee SE (2016) Plasma glutathione reductase activity and prognosis of septic shock. J Surg Res 200(1):298-307

36. Winek CL, Wahba WW, Winek CL Jr, Balzer TW (2001) Drug and chemical blood-level data 2001. Forensic Sci Int 122(2-3):107-123

37. Jover R, Ponsoda X, Castell JV, Gómez-Lechón MJ (1994) Acute cytotoxicity of ten chemicals in human and rat cultured hepatocytes and in cell lines: correlation between in vitro data and human lethal concentrations. Toxicol in Vitro 8(1):47-54

38. Baselt RC, Wright JA, Cravey RH (1975) Therapeutic and toxic concentrations of more than 100 toxicologically significant drugs in blood, plasma, or serum: a tabulation. Clin Chem 21(1):44-62

39. European Commission Joint Research Centre (2003) European union risk assessment report hydrogen peroxide CAS No: 7722 84-1 2nd priority list, vol 38

40. Nahum A, Wood LD, Sznajder JI (1989) Measurement of hydrogen peroxide in plasma and blood. Free Radic Biol Med 6(5):479-484

41. Hu HY, Wei SY, Pan CH (2018) Rhabdomyolysis observed at forensic autopsy: a series of 52 cases. Forensic Sci Med Pathol 14(4): 424-431

42. Bagley WH, Yang H, Shah KH (2007) Rhabdomyolysis. Intern Emerg Med 2(3):210-218

43. Connolly GN, Richter P, Alequas A Jr, Pechacek TF, Stanfill SB, Alpert HR (2010) Unintentional child poisonings through ingestion of conventional and novel tobacco products. Pediatrics 125(5):896899

44. Sisselman SG, Mofenson HC, Caraccio TR (1996) Childhood poisonings from ingestion of cigarettes. Lancet 347(8995):200-201

45. Lindstorm J (1997) Nicotinic acetylcholine receptors in health and disease. Mol Neurobiol 15(2):193-222

46. Won WY, Lee CU, Chae JH, Kim JJ, Lee C, Kim DJ (2014) Changes of plasma adiponectin levels after smoking cessation. Psychiatry Investig 11(2):173-178

Publisher's note Springer Nature remains neutral with regard to jurisdictional claims in published maps and institutional affiliations. 